\title{
Diagnosis of carotid and vertebral artery injury in major trauma with head injury
}

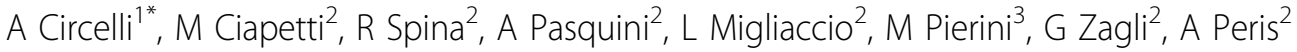 \\ From 30th International Symposium on Intensive Care and Emergency Medicine \\ Brussels, Belgium. 9-12 March 2010
}

\section{Correction}

After the publication of this abstract [1], we found some mistakes in the text. In details:

Methods section: the correct sentence is "We modified these protocol improving screening criteria to all patients with petrous bone fracture, even without carotid canal involvement".

Results section: the correct sentence is "According to our proposed modified Memphis criteria, 53 patients (instead of the 45 if using original Memphis criteria) showed risk factors for BCVI (19.9\% of the total of BMT; $32.7 \%$ of TBI), and 6 of them had carotid injury $(2.2 \%$ of all BMT; $11.3 \%$ of patient with risk factors)".

We regret any inconvenience that this inaccuracy may have caused.

\begin{abstract}
Author details
${ }^{1}$ Postgraduate School of Anesthesia and Intensive Care, Faculty of Medicine, University of Florence, Florence, Italy. ${ }^{2}$ Anesthesia and Intensive Care Unit of Emergency Department, Careggi Teaching Hospital, Florence, Italy.

${ }^{3}$ Meccanical and Technology Department, Faculty of Engineer, University of Florence, Florence, Italy.
\end{abstract}

Published: 7 April 2010

\section{Reference}

1. Circelli A, Ciapetti M, Spina R, Pasquini A, Migliaccio L, Pierini M, G Zagli G, Peris A: Diagnosis of carotid and vertebral artery injury in major trauma with head injury. Critical Care 2010, 14(Suppl 1):P297.

doi:10.1186/cc8921

Cite this article as: Circelli et al:: Diagnosis of carotid and vertebral artery injury in major trauma with head injury. Critical Care 2010 14(Suppl 1):P603.
${ }^{1}$ Postgraduate School of Anesthesia and Intensive Care, Faculty of Medicine, University of Florence, Florence, Italy
Submit your next manuscript to BioMed Central and take full advantage of:

- Convenient online submission

- Thorough peer review

- No space constraints or color figure charges

- Immediate publication on acceptance

- Inclusion in PubMed, CAS, Scopus and Google Scholar

- Research which is freely available for redistribution

Submit your manuscript at www.biomedcentral.com/submit
C Biomed Central 